\title{
Functional risk assessment as part of the validation in the implementation of chromatography data system
}

\author{
Mena Ivanoska $^{1 *}$, Hristina Babunovska $^{1}$, Rumenka Petkovska ${ }^{2}$ \\ ${ }^{1}$ Alkaloid AD-Skopje, Pharmaceutical, Chemical and Cosmetics Industry, \\ blvd. Aleksandar Makedonski 12, 1000 Skopje, Republic of Macedonia \\ ${ }^{2}$ Faculty of Pharmacy, Ss. Cyril and Methodius University, \\ Mother Theresa St. 47, 1000 Skopje, Republic of Macedonia
}

Received: July 2018; Accepted: August 2018

\begin{abstract}
A Chromatography Data System (CDS) is a complex software that can be configured to the specific needs of the user's business process. As such it falls into the Good Automated Manufacturing Practice (GAMP) 5 Category 4 - Configured Products. The validation process is planned and follows along the phases proposed by GAMP 5 for configured products.

The Risk assessment stage of the CDS validation process is to carry out a risk assessment of each function of the User Requirements Specification (URS) determined on if the function is regulatory risk critical or not. The functional risk assessment is made according to the method- Failure Mode and Effects Analysis (FMEA).

The Overall Risk resulting from the Risk Assessment has identified all potential failures requiring mitigating actions/controls. Mitigating actions and testing controls during the PQ phase is implemented.

The final Overall Risk after implementation of Mitigating actions and testing controls during the PQ phase is not more than Medium.
\end{abstract}

Keywords: chromatography data system, validation of the CDS Software, risk assessment, laboratory data integrity

\section{Introduction}

The integrity of laboratory data is crucial for audits and regulatory inspections. Compromised data impacts a manufacturer's bottom line and threatens the availability of therapeutic medicines. The industry is facing great pressure to produce pharmaceuticals at low cost while adhering to the highest safety and data integrity expectations. To meet the challenging regulators demands of quality-driven, internal inspectors and safety-driven, government, manufacturers are turning to innovative Information Technology (IT) infrastructures (ISPE's Annual meeting, 2014). One of the aims of data governance should not be a way to keep the regulators happy, but to ensure the survival and growth of organizations (McDowall, 2016; McDowall, 2017). So, from the perspectives of regulatory compliance and practical use of the system, a networked Chromatography Data System (CDS) solution is the only option that should be considered for regulated laboratories (McDowall and Burgess, 2015). CDS is vital for efficient and reliable operation of any modern chromatography laboratory - it must manage all the analytical processes from instrument control, to raw data storage and processing, right through to generating the final results. CDS using validated reports and calculations should be classified as Good Automated Manufacturing Practice (GAMP) category 4. This means that all commercial CDS software's are

\footnotetext{
* mivanoska1@alkaloid.com.mk
} 
required to have configurations to acquire data from the chromatography instruments from different vendors, which are connected into the CDS, and to control those instruments. Therefore, the objectives regarding the life cycle and the validation of the CDS should be based on GAMP "V model" (GAMP 4, 2001).

The aim of this paper will be the Functional Risk Assessment as part of the validation, planned for implementation of the CDS (McDowall, 2006) which is setup at laboratories at drug manufacturing industry. CDS is based on Chromeleon ${ }^{\mathrm{TM}}$ Chromatography Data System (CDS) software from vendor Thermo Scientific ${ }^{\mathrm{TM}}$ (thermofisher.com). It will be used by the Research and Development (R\&D), Quality Control (QC) and Quality Assurance (QA) departments for their chromatographic analyses and any required reporting or evaluation of obtained data.

The objective of the Functional Risk Assessment is to evaluate requirements as defined in the User Requirements Specification regarding their GMP risks and to identify mitigating actions or other controls to be established to reduce the risk identified.

\section{Validation of the CDS Software}

\section{Life cycle approach to validation of the CDS Software}

The CDS based on Chromeleon Software will be used within a GMP regulated environment and as such it falling under the regulatory requirements (EudraLex, 2011; FDA, 2003; FDA, 2016; MHRA, 2015; MHRA, 2018; OMCL, 2018; WHO, 2016) and industry guidelines and standards (GAMP, 2005; GAMP, 2005; GAMP, 2012a; GAMP, 2012b; GAMP, 2017). The R\&D, QC and QA departments are able to connect to this central infrastructure via the corporate network locally or remotely. They operate their Chromatographic instruments via Instrument PC (IPC) computers but also have workstations as separate access points to the system. QA is provided with access to the relevant data also via workstations. There are two environments maintained, one for test and one for production use. Both environments have their own Chromeleon Sofware installed.

To complete a System Life Cycle phase, it is required to have the phase related documents in an approved state. Based on the classification of the CDS as Configured Product (GAMP 5 Category 4) the following Life Cycle Approach has been chosen:

\section{Planning Phase}

During the planning Phase a CDS, Chromeleon has been selected based on the URS Project Documentation software system implementation. The Project has been planned and a Project Organization has been setup. The Planning Phase will be concluded by approving the systems Validation Plan.

\section{Specification Phase}

During the Specification Phase a User Requirements Specification is being produced detailing the general CDS user requirements as well as more specific implementation requirements resulting from the laboratory business processes. The URS Project Documentation software system implementation, used during the Software Selection process will serve as basis of Validation Plan.

A Risk Assessment of the planned systems functions will then be carried out based on the user requirements.

A Functional Specification will be produced, covering any functionality used that is not covered by the Chromeleon Standard Documentation.

The planned Configuration of the System will then be described in a Configuration Specification.

The Specification Phase can be concluded once all the related documents have been approved. An additional formal design review is not planned to be executed as a mandatory task.

\section{Installation and Configuration Phase}

During this phase the system will be installed and configured as described in the Specification Phase.

To conclude this phase, the verification documents required in the next phase need to be available in approved versions.

\section{Verification Phase}

\subsection{Installation Qualification}

The Installation will be verified via an Installation Qualification making use of Chromeleon Standard Documentation where possible.

\subsection{Operational Qualification}

The Operational Qualification can be started once Installation Qualification has been completed and documented in an approved Installation Qualification Report.

The correct configuration of the system and the covering of the user requirements will be verified in this phase. Functional/Black-Box testing is deemed sufficient for that purpose. The depth of the testing will be based on the results of the Risk Analysis and will include positive, negative and limit testing as required. Where possible testing will follow the business processes and related procedures.

It is not the goal of this verification to test standard Chromeleon functionality.

\section{Validation Completion Acceptance Criteria}

The Validation is completed once the Validation Report has been approved. To allow acceptance of the validation it is required that all validation phases have been completed successfully including the required documentation.

In case of open issues, they have to be assessed as part of the validation report and a plan has to be provided 
Table 1. Validation deliverables for CDS

\begin{tabular}{l}
\hline Validation Deliverable \\
\hline Chromeleon Documentation - Validation Plan \\
Chromeleon Documentation - User Requirements Specification \\
Chromeleon Documentation - Functional Requirements Specification \\
Chromeleon Documentation - System Design Overview \\
Chromeleon Documentation - Configuration Specification \\
Chromeleon Documentation - Functional Risk Assessment \\
Chromeleon Documentation - Installation Qualification Plan and Protocols \\
Chromeleon Documentation - Installation Qualification Plan and Protocols (executed) including Installation \\
Summary Report \\
Chromeleon Documentation - Operational Qualification \\
Chromeleon Documentation - Operational Qualification (executed) including OQ Summary Report \\
Chromeleon Documentation - Trace Matrix \\
Chromeleon Documentation - Validation Report \\
Chromeleon Documentation - System Release
\end{tabular}

how, when and by whom they will be resolved and how follow up will be guaranteed.

A release of the system is possible only when all issues deemed relevant for the correct functioning of the system have been resolved or robust workarounds have been defined.

\section{System Release}

The System will be released for production use by a separate formal step after validation is completed, initial users and support personnel have been trained and the validation system has been prepared to be used as production system.

Further Rollout of the system will be planned and followed up in separate Rollout Plans.

The objectives regarding the life cycle and the validation of the CDS should be based on GAMP "V model" (DeSpautz et al., 2008). As shown in the figure 1 (with the green division line), there is a division between the user of the CDS software and the supplier of the CDS software. The left-hand side of the $\mathrm{V}$ represents the design stages of the CDS software, the bottom is the software installation stage and the right-hand side of the $\mathrm{V}$ represents the testing stages of the life cycle.

This $\mathrm{V}$ model is used to generate the validation deliverables during the CDS development life cycle and the documents that are produced during the CDS development life cycle are presented in Table 1 . The key validation deliverable, the Functional Risk Assessment will be discussed in more detail in the next sections. Taken together all of these documents will provide the validation package to support the system release declaration that the chromatography data system is fit for purpose, validated and released for production use.

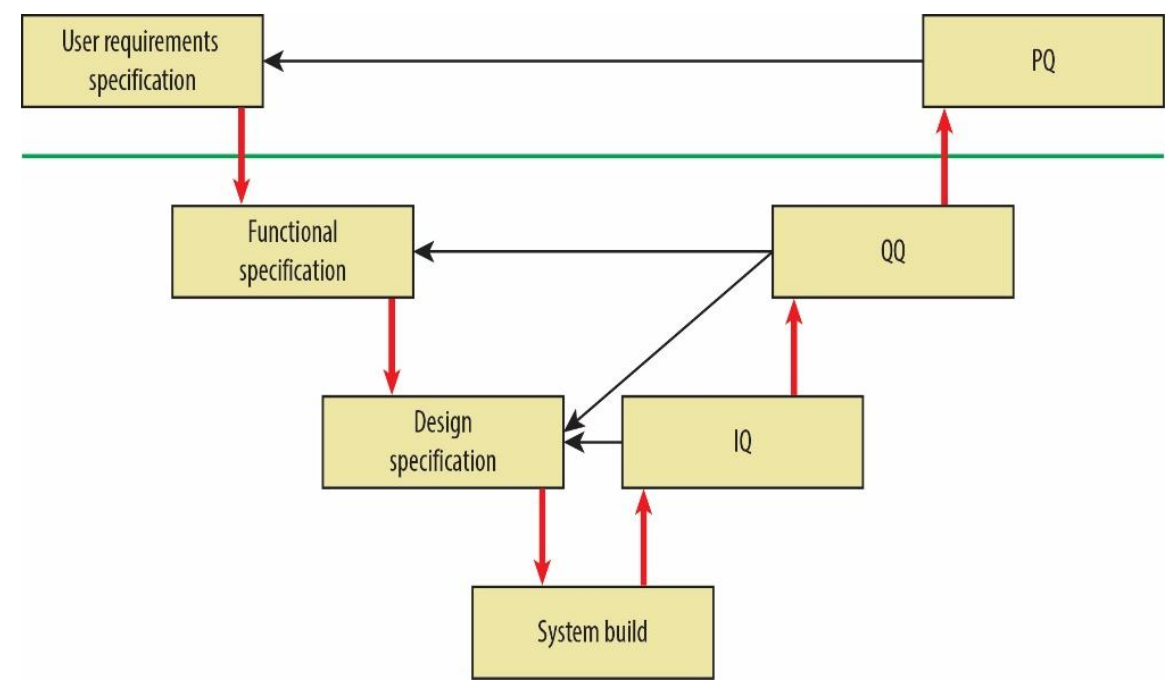

Fig. 1. Chromatography data system development life cycle. 
Risk Assessment Approach to validation of the CDS Software

The chosen risk assessment approach (FDA, 2006; ICH, 2005; WHO, 2013) aims to establish controls such that the combination of severity, probability and detectability of failures is reduced to an acceptable level, with:

- Severity possible impact of failure, as shown in Table 2;

- Probability likelihood of the failure to happen, as shown in Table 3;

- Detectability likelihood of the failure to be detected timely, as shown in Table 4.

The following definitions will apply throughout this functional risk assessment:

Each potential failure is assessed in 2 steps:

1. Severity of impact on patient safety, product quality and data integrity against Probability of the failure to happen resulting in a Risk Class, as shown on Figure 2.

2. Risk Class against Detectability (likelihood of detection) resulting in an Overall Risk, as shown on Figure 3.

The Overall Risk resulting from the Risk Assessment is used to identify potential failures requiring mitigating actions/controls to be implemented.

These actions/controls are typically aimed at:

- eliminating risk through process or system redesign

- reducing the overall risk by reducing the probability of a failure occurring

- reducing the overall risk by increasing the inprocess detectability of the failure

Mitigating actions should be defined where possible even when the Overall Risk is already at an acceptable level.

The final Overall Risk after implementation of mitigation actions/controls should be no more than Medium.

\section{Results and discussion}

The Risk assessment stage of the CDS validation process is to carry out a risk assessment of each function of the User Requirements Specification (URS) determined on if the function is regulatory risk critical or not. The tables from the URS and the Functional specification have additional columns added to, in order to evaluate the regulatory risk. The functional risk assessment following the Failure Mode and Effects Analysis (FMEA) method (Stamatis, 2003; Spectroscopy Editors, 2006) will be executed based on the requirements described in the URS. The risk assessment has focused on the identification of functions with impact on patient safety, product quality and data integrity and specifically to identify any areas of high risk requiring additional controls. It has also been a goal of the risk assessment to allow a more risk focused functional testing.

The risk assessment outlined here is to take only those functions related to functional requirements that are classified as critical and consider them for testing in the performance qualification phase (PQ) of the validation. In this way, requirements are prioritized and classified for risk and the most critical one can be traced to the PQ test script.

Table 2. Severity Levels

\begin{tabular}{ll}
\hline \hline Severity Level & Definition \\
\hline High & Potential severe impact on patient safety and/or product quality \\
Medium & Potential impact on patient safety and/or product quality and/or major compliance issue \\
Low & No impact on patient safety and/or product quality and/or minor compliance issue \\
\hline
\end{tabular}

Table 3. Probability of Occurrence Level

\begin{tabular}{ll}
\hline \hline Probability Level & Definition \\
\hline High & Likely to occur - more than twice a year \\
Medium & Likely to occur very rarely - once or twice a year \\
Low & Unlikely - expected to occur less than once a year \\
\hline
\end{tabular}

Table 4. Probability of Detection Levels

\begin{tabular}{ll}
\hline \hline Detection Level & Definition \\
\hline High & Likely to be detected promptly - close to 100\% detection expected \\
Medium & $\begin{array}{l}\text { Likely to be detected, maybe slightly delayed - more than 75\% detection expected } \\
\text { Potentially to be missed or to be detected with severe delay - less than 75\% detection } \\
\text { Low }\end{array}$ \\
\hline
\end{tabular}






Fig. 2. Resulting Risk Class: 1- High, 2- Medium, 3-Low.

The Overall Risk resulting from the Risk Assessment has identified all potential failures requiring mitigating actions/controls. Mitigating actions and testing controls during the PQ phase should be implemented.

Mitigating actions has not been defined where the Overall Risk is already at an acceptable level. The final Overall Risk after implementation of Mitigating actions and testing controls during the PQ phase is not more than Medium.

\section{Conclusion}

The Functional Risk Assessment as part of the validation process for the CDS implementation has been completed. The requirements as defined in the User Requirements Specification have been evaluated regarding their GMP risks and mitigating actions or other controls has been identified. The final scope of the validation process has been completed. The objectives of this validation process were to have a GMP compliant CDS in place which can be easily expanded to include more users, instruments; laboratories and sites while maintaining its compliant state. All validation phases have been completed successfully including the required documentation.

\section{Acknowledgement}

The author would like to thank Alkaloid AD-Skopje, Pharmaceutical, Chemical and Cosmetics Company, for support, comments and suggestions made during the writing of this paper.

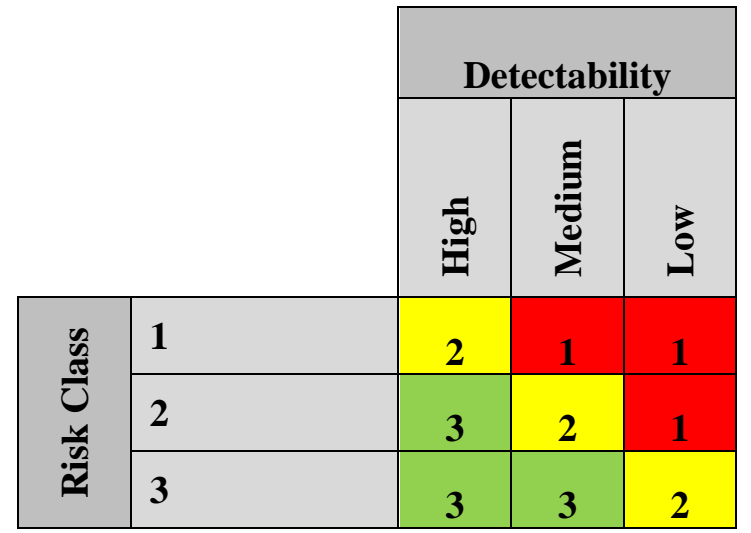

Fig. 3. Resulting Overall Risk: 1- High, 2- Medium, 3-Low.

\section{References}

DeSpautz, J., Kovacs, K.S., Werling, G., 2008. GAMP Standards for validation of automated systems. Available at:

https://www.academia.edu/39999095/GAMP_Standards_For_V alidation_Of_Automated_Systems_Strategies_to_validate_ automated_systems_while_balancing_internal_and_externa 1_demands_Whats_GAMP.

European Commission Health and Consumers DirectorateGeneral, Eudralex, 2011. The rules governing medicinal products in the European Union, Volume 4: Good manufacturing practice, Medicinal products for human and veterinary use, Part I and Annexes specifically - Annex 11 Computerized systems. Available at:

https://ec.europa.eu/health/sites/health/files/files/eudralex/v ol-4/annex11_01-2011_en.pdf.

Food and Drug Administration (FDA), 21 Code ofFederal Regulations (CFR) Part 11, 2003 (up-to-date version eCFR). Part 210 Current good manufacturing practice in manufacturing, processing, packing, or holding of drugs; General, Part 211 Current good manufacturing practice for finished pharmaceuticals. Available at: https://www.accessdata.fda.gov/scripts/cdrh/cfdocs/cfefr/C FRSearch.cfm?CFRPart=211\&showFR=1.

Food and Drug Administration (FDA), 2006. Guidance for industry: Q9 Quality risk management. Available at: https://www.fda.gov/media/71543/download.

Food and Drug Administration (FDA), 2016. Guidance for industry: Data integrity and compliance with cGMP. Available at:

https://www.fda.gov/files/drugs/published/Data-Integrityand-Compliance-With-Current-Good-ManufacturingPractice-Guidance-for-Industry.pdf.

Good Automated Manufacturing Practice (GAMP), 2001. Guidelines version 4. International society for pharmaceutical engineering (ISPE), Tampa, Florida. 
Table 5. Functional risk assessment for Functional Requirements

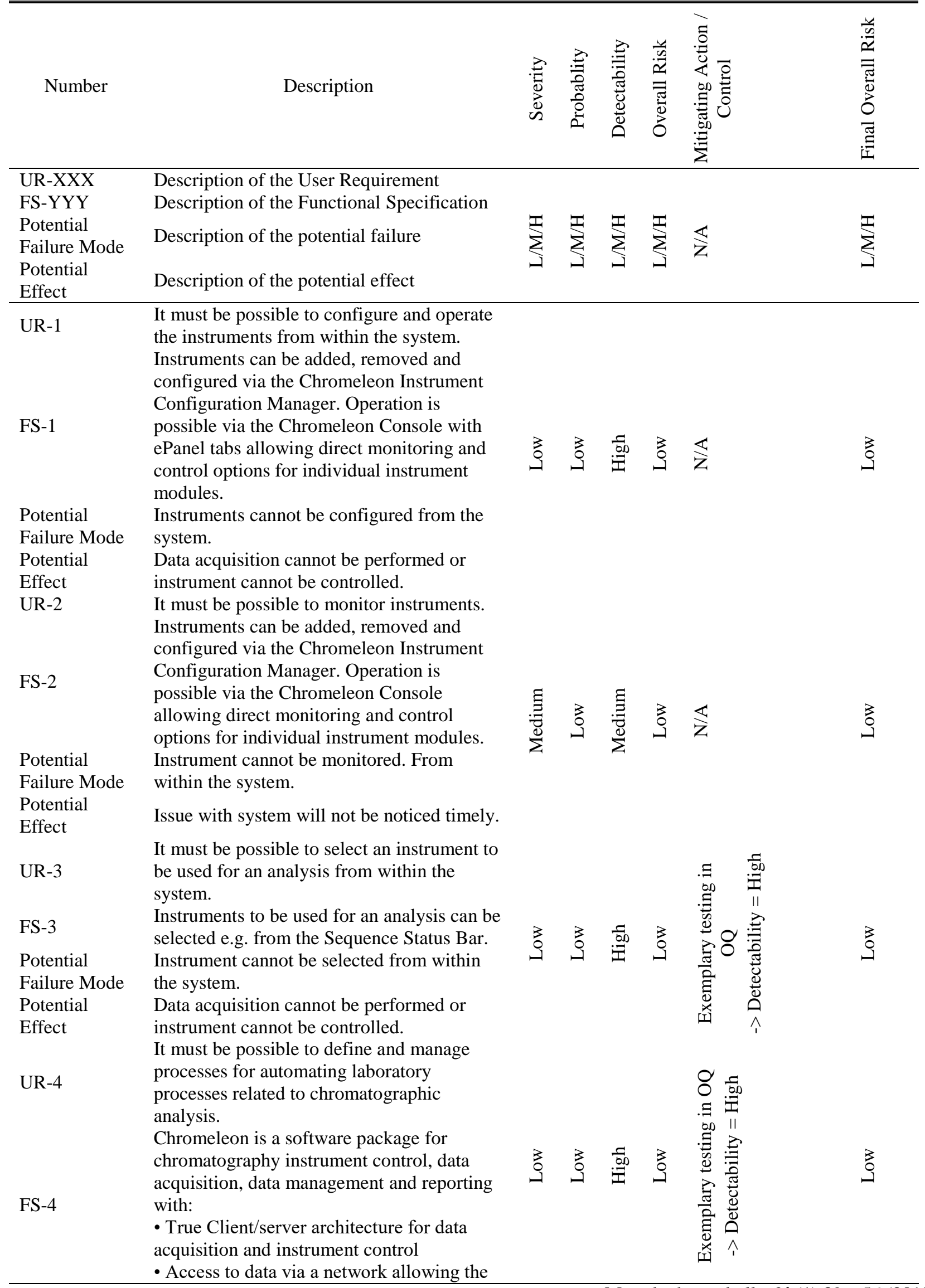




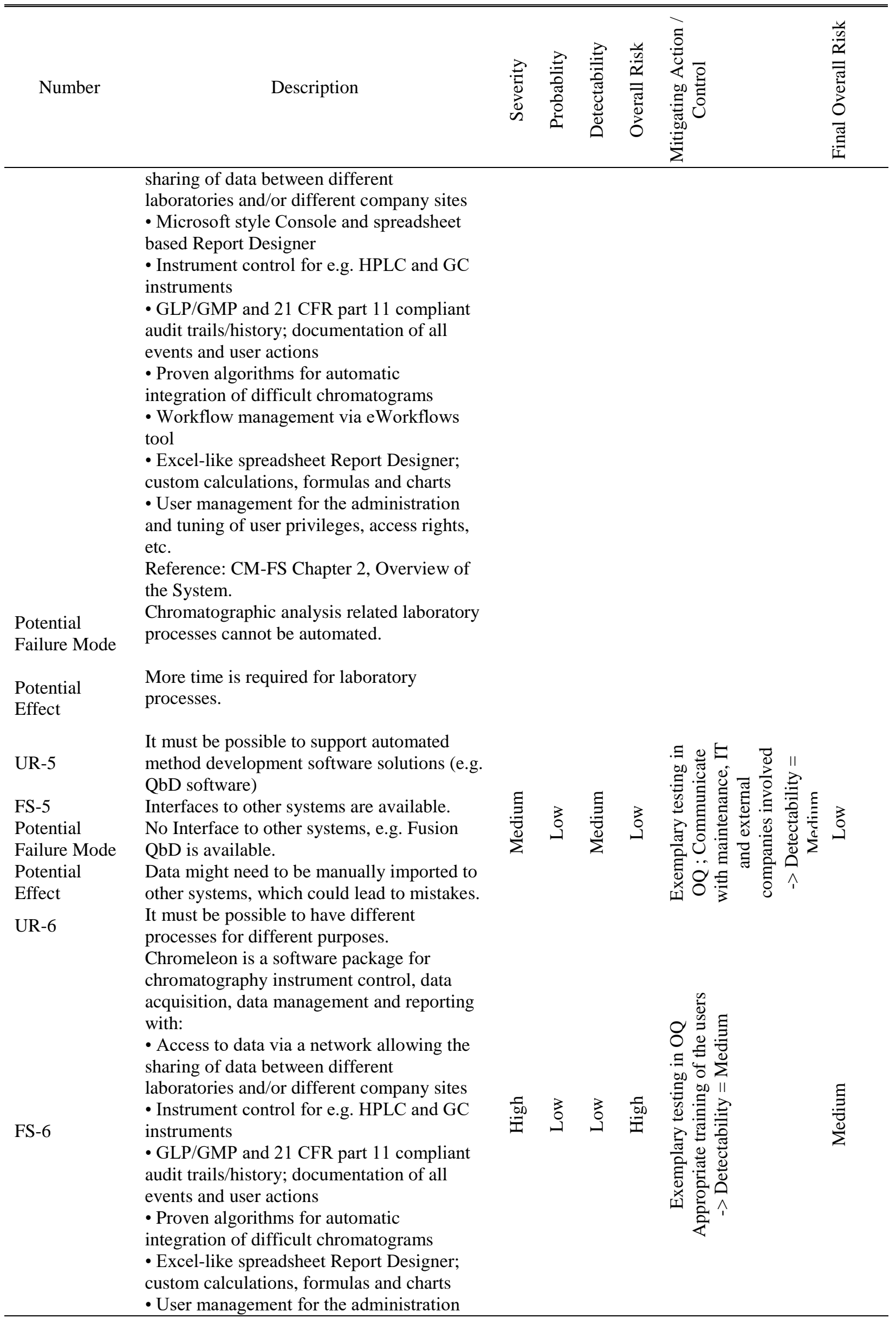














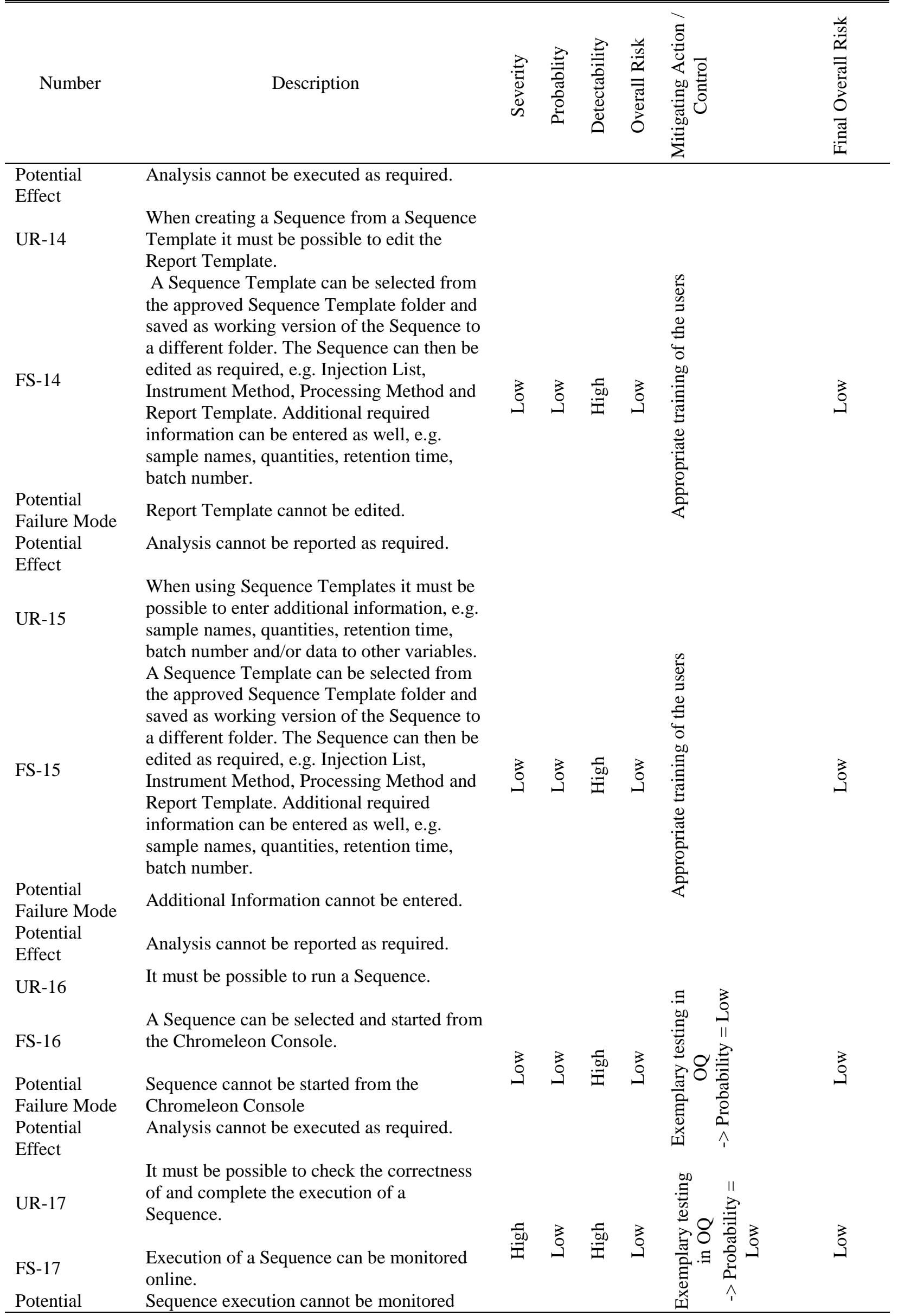




\begin{tabular}{|c|c|c|c|c|c|c|c|}
\hline Number & Description & 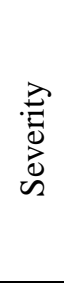 &  & 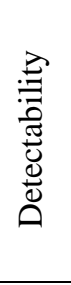 & 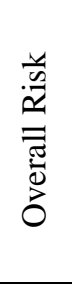 &  &  \\
\hline Failure Mode & online. & & & & & & \\
\hline $\begin{array}{l}\text { Potential } \\
\text { Effect }\end{array}$ & $\begin{array}{l}\text { Issues with the execution of the sequence } \\
\text { might not be detected timely. }\end{array}$ & & & & & & \\
\hline UR-18 & $\begin{array}{l}\text { It must be possible to attach additional } \\
\text { documentation to a Sequence. }\end{array}$ & & & & & $\stackrel{D}{E}$ & \\
\hline FS-18 & $\begin{array}{l}\text { Additional documentation can be added to a } \\
\text { Sequence by right-clicking on the } \\
\text { Associated Items area and selecting Add } \\
\text { Attachment. }\end{array}$ & 3 & 3 & 氙 & 3 &  & 3 \\
\hline $\begin{array}{l}\text { Potential } \\
\text { Failure Mode }\end{array}$ & $\begin{array}{l}\text { No additional documentation can be added } \\
\text { to the sequence. }\end{array}$ & & & & & & \\
\hline $\begin{array}{l}\text { Potential } \\
\text { Effect }\end{array}$ & $\begin{array}{l}\text { Additional documentation has to be stored } \\
\text { and managed at a different place. }\end{array}$ & & & & & 产 & \\
\hline UR-19 & $\begin{array}{l}\text { It must be possible to make a Sequence } \\
\text { Read-Only. }\end{array}$ & & & & & .9 & \\
\hline FS-19 & $\begin{array}{l}\text { A sequence can be protected by setting it to } \\
\text { read-only (e.g. via read-only checkbox on } \\
\text { the sequence properties window). }\end{array}$ & 동 & $\Xi$ & $\stackrel{\Xi}{\Xi}$ & .60 & 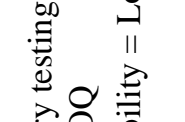 & 䒠 \\
\hline $\begin{array}{l}\text { Potential } \\
\text { Failure Mode }\end{array}$ & $\begin{array}{l}\text { Sequence cannot be protected by setting it to } \\
\text { read-only. }\end{array}$ & 可 & $\sum_{\Sigma}^{e}$ & $\sum^{\infty}$ & 诖 & & $\sum_{\Sigma}^{\infty}$ \\
\hline $\begin{array}{l}\text { Potential } \\
\text { Effect }\end{array}$ & $\begin{array}{l}\text { Changes to finalized sequence might be } \\
\text { applied by mistake. }\end{array}$ & & & & & $\begin{array}{ll}\overrightarrow{\bar{D}} & \vec{D} \\
\vec{I} & \hat{\imath}\end{array}$ & \\
\hline UR-20 & $\begin{array}{l}\text { It must be possible to create a Sequence } \\
\text { without using an approved Sequence } \\
\text { Template. }\end{array}$ & & & & & $\begin{array}{l}8 \\
0 \\
\Xi \\
0\end{array}$ & \\
\hline FS-20 & $\begin{array}{l}\text { A Sequence can be created from the } \\
\text { Chromeleon Console via Create Sequence. }\end{array}$ & & & & & & 忢 \\
\hline $\begin{array}{l}\text { Potential } \\
\text { Failure Mode }\end{array}$ & $\begin{array}{l}\text { Sequence cannot be created without } \\
\text { approved Sequence Template. }\end{array}$ & (o & o & .00 & o & & $\sum^{i}$ \\
\hline $\begin{array}{l}\text { Potential } \\
\text { Effect }\end{array}$ & $\begin{array}{l}\text { Flexibility is lost as always an approved } \\
\text { Sequence Template has to be created first. }\end{array}$ & & & & & 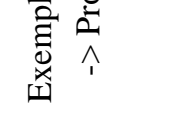 & \\
\hline UR-21 & $\begin{array}{l}\text { It must be possible to edit a Sequence after } \\
\text { its starting including Processing Method, } \\
\text { Report Template and Instrument Method. It } \\
\text { must also be possible to add injections. }\end{array}$ & & & & & & \\
\hline FS-21 & $\begin{array}{l}\text { A sequence can be controlled and monitored } \\
\text { while being executed. Execution can be } \\
\text { paused, resumed or stopped completely. } \\
\text { Changes can then be applied as required. }\end{array}$ & $\stackrel{50}{60}$ & 3 & $\stackrel{\sqrt[50]{60}}{i=1}$ & 3 & $\overleftrightarrow{\mathrm{z}}$ & 旁 \\
\hline $\begin{array}{l}\text { Potential } \\
\text { Failure Mode }\end{array}$ & $\begin{array}{l}\text { Sequence cannot be edited after start of } \\
\text { execution. }\end{array}$ & & & & & & \\
\hline $\begin{array}{l}\text { Potential } \\
\text { Effect }\end{array}$ & $\begin{array}{l}\text { Reduced flexibility as short-term changes } \\
\text { cannot be applied. }\end{array}$ & & & & & & \\
\hline UR-22 & $\begin{array}{l}\text { It must be possible to differentiate the Status } \\
\text { an Instrument or Processing Method is in } \\
\text { (Draft, Approved). }\end{array}$ & & & & & 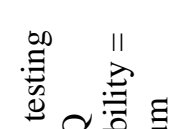 & \\
\hline FS-22 & $\begin{array}{l}\text { There is no status assigned by Chromeleon } \\
\text { to an Instrument- or Processing Method. To } \\
\text { differentiate between Methods in different } \\
\text { development / approval status a process is }\end{array}$ & $\stackrel{\overline{60}}{\overrightarrow{1}}$ & 3 & 30 & $\stackrel{\frac{5}{00}}{i \pm}$ & 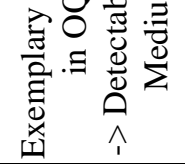 & $\stackrel{\bar{z}}{\sum^{e}}$ \\
\hline
\end{tabular}




\begin{tabular}{|c|c|c|c|c|c|c|c|}
\hline Number & Description & 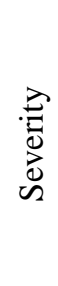 &  & 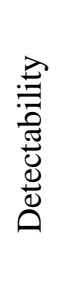 & 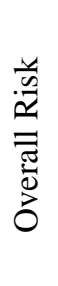 & 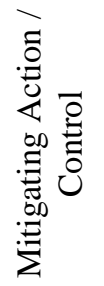 & 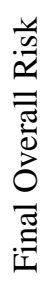 \\
\hline
\end{tabular}

\begin{tabular}{ll}
\hline & $\begin{array}{l}\text { defined where the Methods will be stored in } \\
\text { different folders. Key User role will be able } \\
\text { to create Methods in a draft folder and move } \\
\text { them after approval to the approved folder. }\end{array}$ \\
Potential & $\begin{array}{l}\text { Status of Instrument / Processing Method } \\
\text { cannot be differentiated. }\end{array}$
\end{tabular}

Potential

A method in Draft status might be used.

Effect

It must be possible to select/edit a Method

UR-23 from a group of approved Methods.

(Instrument / Processing).

There is no status assigned by Chromeleon to an Instrument- or Processing Method. To differentiate between Methods in different

FS-23 development / approval status a process is defined where the Methods will be stored in different folders. Key User role will be able to create Methods in a draft folder and move them after approval to the approved folder.

Potential It is not possible to select / edit an approved

Failure Mode method.

Potential

A method in Draft status might be used or $n$

Effect approved method cannot be edited

UR-24

It must be possible to move a Method to another storage location which is part of the system.

A user will be able to move a Method to

FS-24 another storage location as long as the roles privileges and the users access groups permit.

Potential Method cannot be moved to another storage Failure Mode location.

Potential Methods cannot be shared within the system Effect with different user groups and/ or sites.

UR-25 It must be possible to copy a Method.

A user will be able to copy a Method as long FS-25 as the roles privileges and the users access groups permit such action.

Potential

Failure Mode

Method cannot be copied.

Potential

Effect

Methods cannot be shared or used as basis for the development of a new method. It must be possible to use electronic

UR-26 signatures.

FS-26

Chromeleon supports the use of electronic signatures for Submit, Review and Approve for Sequences.


Potential

Failure Mode

No electronic signatures can be used.






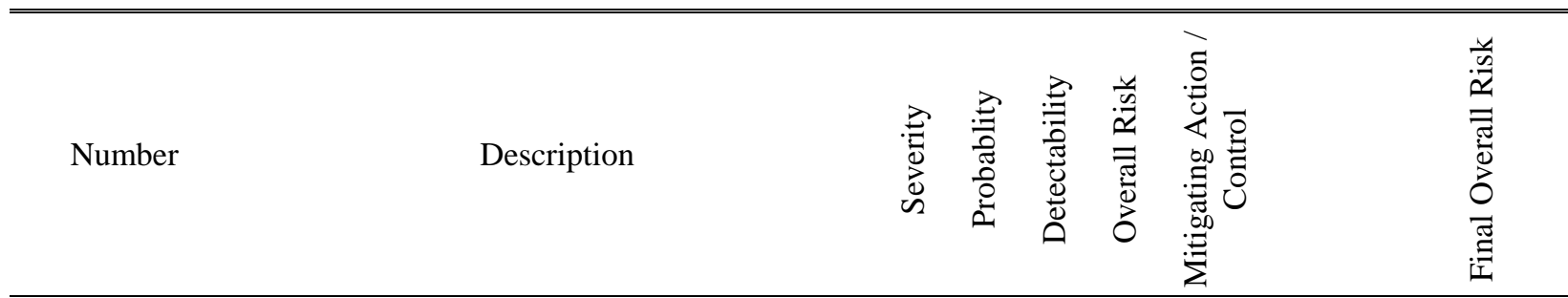

Required signatures could not be managed by the system and the data would not be automatically protected against change.

Potential

Effect

UR-27 including process steps requiring electronic signatures.

Chromeleon allows defining the required signatures as part of the Sequence Properties

FS-27 if Modify Signature Requirements has been granted. By default electronic signatures for Submit, Review and Approve are enabled.

Potential It is not possible to define process steps

Failure Mode requiring an electronic signature.

Potential

Effect

Required signatures could not be managed by the system and the data would not be automatically protected against change. It must be possible to lock a Sequence using

UR-28 an electronic signature after an analysis has been completed. (Submit).

After a Sequence has been electronically

FS-28 signed, e.g. Submit, the Sequence cannot be modified without revoking the signature first.

Potential Sequence data is not automatically protected Failure Mode after Submit signature has been executed.

Potential Sequence data could be modified by

Effect mistake.

UR-29 It must be possible to ensure that Submitter, Reviewer and Approver are different users. As a User Database Policies setting it will be defined that Submitter, Reviewer and Approver have to be different users.

Potential Failure Mode

Potential

Effect Submitter, Reviewer and Approver are not required to be different users Analyst could review / approve his own activities / results.
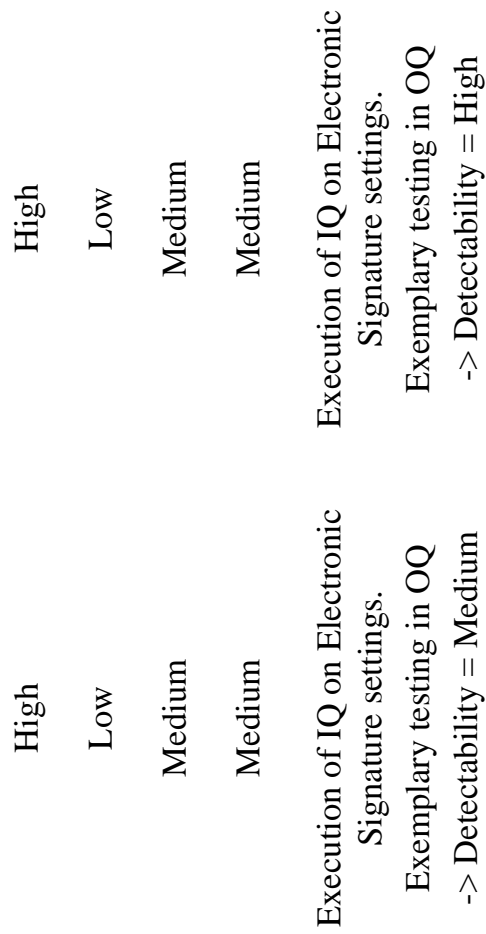

$\stackrel{\Xi}{:}$



$\sum^{\Xi}$

UR-30 It must be possible to e-sign to complete review.

Chromeleon allows defining the required

FS-30 signatures as part of the Sequence Properties if Modify Signature Requirements has been granted. By default electronic signatures for 


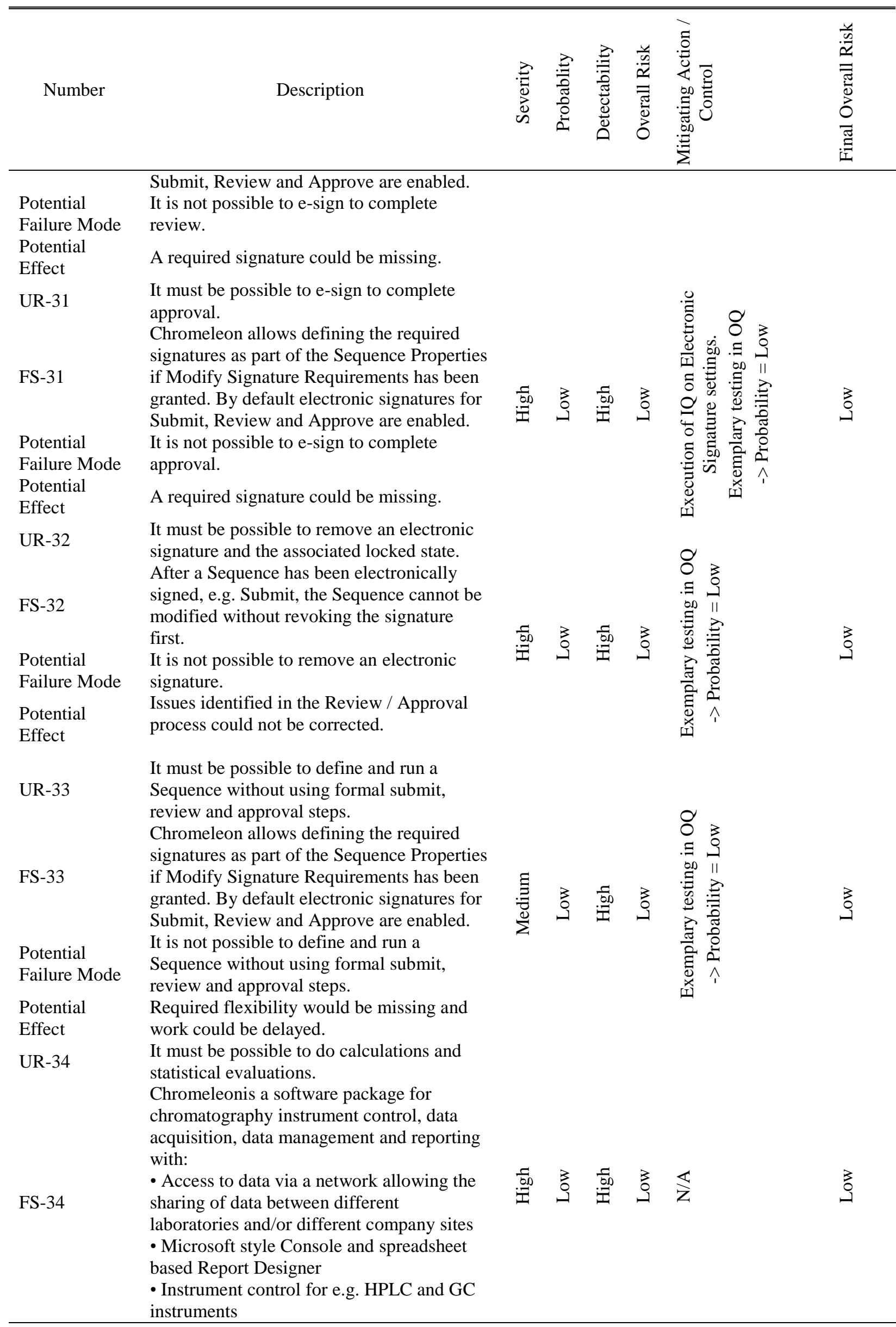




\begin{tabular}{|c|c|c|c|c|c|c|c|}
\hline Number & Description & 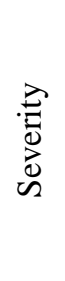 & 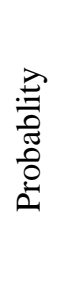 & 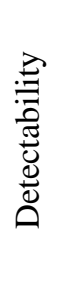 & 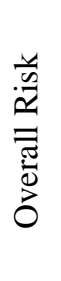 & 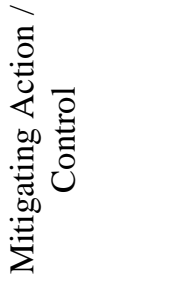 & 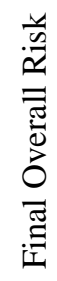 \\
\hline $\begin{array}{l}\text { Potential } \\
\text { Failure Mode } \\
\text { Potential } \\
\text { Effect }\end{array}$ & $\begin{array}{l}\text { - GLP/GMP and } 21 \text { CFR part } 11 \text { compliant } \\
\text { audit trails/history; documentation of all } \\
\text { events and user actions } \\
\text { - Proven algorithms for automatic } \\
\text { integration of difficult chromatograms } \\
\text { • Workflow management via eWorkflows } \\
\text { tool } \\
\text { • Excel-like spreadsheet Report Designer; } \\
\text { custom calculations, formulas and charts } \\
\text { - User management for the administration } \\
\text { and tuning of user privileges, access rights, } \\
\text { etc. } \\
\text { It is not possible to do calculations and } \\
\text { statistical evaluations as required. } \\
\text { Data measured cannot be evaluated, } \\
\text { interpreted and reported as required. }\end{array}$ & & & & & & \\
\hline UR-35 & $\begin{array}{l}\text { It must be possible to use the system for the } \\
\text { qualification testing of the equipment. } \\
\text { The built-in Instrument Installation } \\
\text { Qualification (IQ) can be used to perform a } \\
\text { general function check which tests the } \\
\text { connection from the instrument controller to } \\
\text { the instrument. }\end{array}$ & .50 & 藏 & .50 & 䓵 & 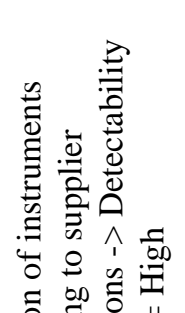 & 沓 \\
\hline $\begin{array}{l}\text { Potential } \\
\text { Failure Mode }\end{array}$ & $\begin{array}{l}\text { System cannot be used for qualification } \\
\text { testing of the equipment. }\end{array}$ & & & & &  & \\
\hline $\begin{array}{l}\text { Potential } \\
\text { Effect }\end{array}$ & $\begin{array}{l}\text { The built-in Instrument Installation } \\
\text { Qualification (IQ) cannot be used. }\end{array}$ & & & & & 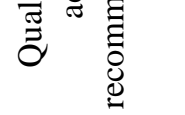 & \\
\hline FS-36 & $\begin{array}{l}\text { It must be possible to create Custom } \\
\text { Variables for entering information / values } \\
\text { or to be used for calculations. } \\
\text { A Custom Variables Editor is available for } \\
\text { defining Custom Variables in the } \\
\text { Chromeleon Console. }\end{array}$ & & & & & 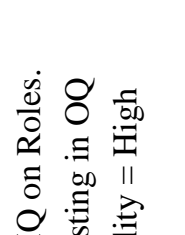 & \\
\hline $\begin{array}{l}\text { Potential } \\
\text { Failure Mode }\end{array}$ & $\begin{array}{l}\text { Custom Variable / Custom Formulas cannot } \\
\text { be created. }\end{array}$ & 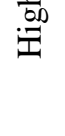 & 年 & i. & 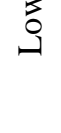 & 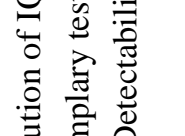 & 3 \\
\hline $\begin{array}{l}\text { Potential } \\
\text { Effect }\end{array}$ & $\begin{array}{l}\text { Data measured cannot be evaluated, } \\
\text { interpreted and reported as required. }\end{array}$ & & & & & 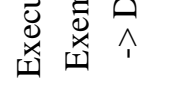 & \\
\hline UR-37 & It must be possible to monitor processes. & & & & & & \\
\hline FS-37 & $\begin{array}{l}\text { A sequence can be monitored in the work } \\
\text { area of the Chromeleon Console when the } \\
\text { data category bar is selected. }\end{array}$ & & & & & 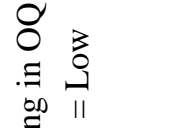 & \\
\hline $\begin{array}{l}\text { Potential } \\
\text { Failure Mode }\end{array}$ & Sequence cannot be monitored. & .50 & 3 & .5:00 & 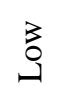 & 莺 & 3 \\
\hline $\begin{array}{l}\text { Potential } \\
\text { Effect }\end{array}$ & $\begin{array}{l}\text { Issues with the execution of the sequence } \\
\text { might not be detected timely. }\end{array}$ & & & & & 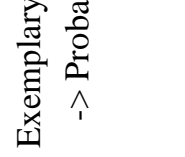 & \\
\hline
\end{tabular}




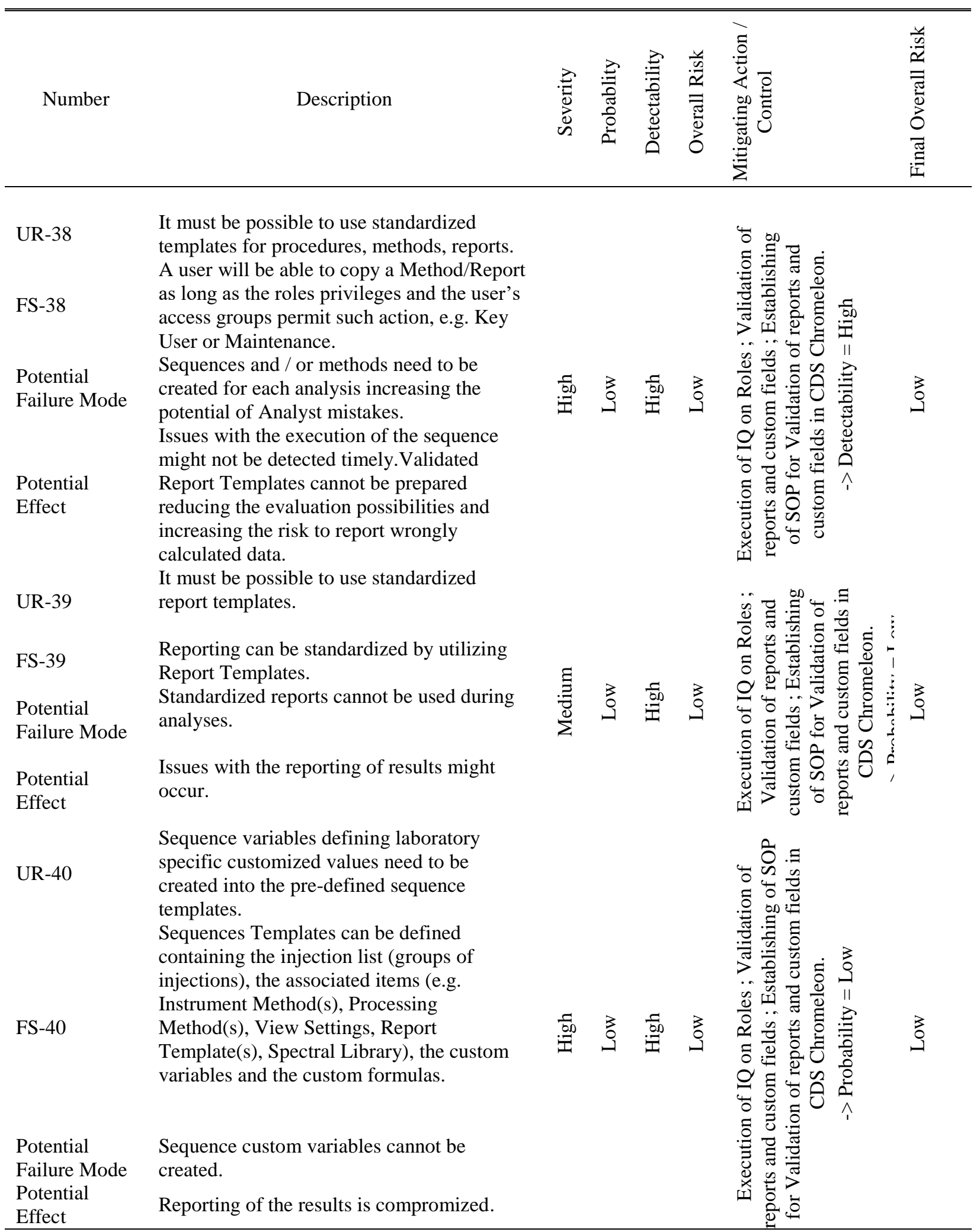


Good Automated Manufacturing Practice (GAMP), 2005. Good practice guide: Validation of laboratory computerized systems. International society for pharmaceutical engineering (ISPE).

Good Automated Manufacturing Practice (GAMP) 5, 2008. Good practice guide: A risk-based approach to compliant GxP computerized systems. International society for pharmaceutical engineering (ISPE).

Good Automated Manufacturing Practice (GAMP), 2012a. Good Practice Guide: A risk-based approach to GxP compliant laboratory computerized systems.International society for pharmaceutical engineering (ISPE).

Good Automated Manufacturing Practice (GAMP), 2012b. Good Practice Guide: A Risk-Based Approach to testing of GxP Systems.International society for pharmaceutical engineering (ISPE).

Good Automated Manufacturing Practice (GAMP), 2017. Good Practice Guide: Records and Data Integrity.International society for pharmaceutical engineering (ISPE).

International conference on harmonization of technical requirements for registration of pharmaceuticals for human use (ICH), 2005. Harmonised Tripartite Guideline: Quality Risk Management Q9. Available at:

https://www.ema.europa.eu/en/documents/scientificguideline/international-conference-harmonisation-technicalrequirements-registration-pharmaceuticals-human-use_en3.pdf.

McDowall, R.D., 2006. A practical and cost effective risk assessment for the validation of commercial laboratory computerized systems. Applied Clinical Trials. Available at: https://alfresco.ubm-us.net.

McDowall, R.D., Burgess, C., 2015. The ideal chromatography data system for a regulated laboratory, Part II: System architecture requirements. LCGC North America 33(10), 782-785. Available at:

http://www.chromatographyonline.com/ideal-

chromatography-data-system-regulated-laboratory-part-iisystem-architecture-requirements.

McDowall, R.D., 2016. Validation of chromatography data systems: Ensuring data integrity, meeting business and regulatory requirements, second ed. Royal Society of Chemistry, Cambridge.

McDowall, R.D., 2017. Understanding data governance, Part II. Spectroscopy, 32(4), 12-18.
Medicines and Healthcare products Regulatory Agency (MHRA), 2015. GMP Data integrity definitions and guidance for industry. Available at:

http://www.spectroscopyonline.com/understanding-datagovernance-part-ii.

Medicines and Healthcare products' Regulatory Agency (MHRA), 2018. GXP Data integrity guidance and definitions. Available at:

https://assets.publishing.service.gov.uk/government/upload s/system/uploads/attachment_data/file/687246/MHRA_Gx P_data_integrity_guide_March_edited_Final.pdf.

Official Medicines Control Laboratory (OMCL) Guideline, 2018. Validation of computerized systems, PA/PH/OMCL (08) 69 R7. Available at: https://www.edqm.eu/sites/default/files/guidelines-omclcomputerised_systems-core_document-march2018.pdf.

Stamatis, D.H., 2003. Failure mode and effect analysis. FMEA from theory to execution, 2nd ed. Milwaukee, American Society for Quality, Quality Press.

Spectroscopy Editors, 2006. Validation of spectrometry software: Risk analysis methodologies for commercial spectrometer software. Spectroscopy, 21(7). Available at: http://www.spectroscopyonline.com/validation-

spectrometry-software-risk-analysis-methodologiescommercial-spectrometersoftware 2 id=\&sk=\&date $=\& \% 0$ A $\% 09 \% 09 \% 09 \&$ pageID $=2$.

World Health Organization (WHO), 2013.Technical report series, Guidelines on quality risk management, 981, Annex 2. Available at:

https://www.who.int/medicines/areas/quality_safety/quality _assurance/Annex2TRS-981.pdf.

World Health Organization (WHO), 2016. Technical report series, Guidance on good data and records management practices, 996, Annex 5. Available at: https://www.who.int/medicines/publications/pharmprep/W HO_TRS_996_annex05.pdf.

ISPE's Annual meeting, 2014. Making the information systems connection, Available at: https://ispe.org/pharmaceuticalengineering/ispeak/making-information-systemsconnection-ispes-annual-meeting.

Product literature, Brochures, eBooks, Technical notes, White papers, 2018. Available at: https://www.thermofisher.com/chromeleon. 


\title{
Резиме
}

\section{Проценка на ризик за функционалност како дел од валидација при имплементација на систем за хроматографски податоци}

\author{
Мена Иваноска ${ }^{1 *}$, Христина Бабуновска ${ }^{1}$, Руменка Петковска ${ }^{2}$ \\ ${ }^{1}$ Алкалоид АД Скопје, Фармацевтска, Хемиска и Козметичка Индустрија, \\ Бул. Александар Македонски 12, 1000 Скопје, Република Македонија \\ 2 Фармаиевтски Факултет, Универзитет „Св. Кирил и Методиј”, \\ Ул. Мајка Тереза 47, 1000 Скопје, Република Македонија
}

Клучни зборови: систем за хроматографски податоци, валидација на CDS софтвер, ризик анализа, интегритет на податоци во лабораторија

Систем за хроматографски податоци или CDS е комплексен софтвер кој може да се конфигурира за специфичните потреби на деловниот процес на корисникот. Како таков, спаѓa во GAMP 5 Категорија 4 Конфигурирани производи. Процесот на валидација е планиран и ги следи фазите предложени од GAMP 5 за конфигурирани производи.

Фазата на проценка на ризикот од процесот на валидација на CDS е да изврши проценка на ризикот за секоја функција од спецификацијата за кориснички барања (URS). Проценката на ризикот за функционалноста е направена по методот Failure Mode and Effects Analysis (FMEA).

Вкупниот ризик кој произлегува од проценката на ризик ги идентификува сите потенцијални пропусти кои бараат корективни активности/контроли. Корективните мерки и контролни тестови се имплементирани за време на PQ фазата.

Конечниот вкупен ризик по спроведувањето на корективните мерки и контролни тестови во текот на PQ фазата не е повеќе од средно ниво. 